\title{
The role of diversified landscape buffer structures for water quality improvement in an agricultural watershed, North China
}

\author{
X.H. Wang, C.Q. Yin *, B.Q. Shan \\ SKLEAC, Research Center for Eco-Environmental Sciences, \\ Chinese Academy of Sciences, P.O. Box 2871, Beijing 100085, PR China
}

Received 17 February 2004; received in revised form 29 July 2004; accepted 6 September 2004

\begin{abstract}
The quality of water flow crossing through the watershed ecosystem reflects the integrated effects of many processes along water pathways. Experiments were conducted in a headwater agricultural watershed in North China to study the hydrological and ecological interactions between complex landscapes and nitrogen $(\mathrm{N})$ flow. It was found that a series of artificial and natural buffer/detention landscape structures, which include four stone dams (SDs), a roadside grassed ditch (RGD), a vegetated filter strip (VFS), two dry ponds (DPs) and a riparian buffer zone (RBZ), distributed along the ephemeral stream, could effectively reduce the export load of sediment and $\mathrm{N}$ in surface runoff. During rainfall-runoff events, surface flow velocity and runoff volume were reduced from inlet to outlet of each structure. As a result, the retention rate of water by the system was determined to be $50.2 \%$, total suspended solid (TSS) to be $72.7 \%$, total nitrogen (TN) $66.1 \%$, total dissolved nitrogen (TDN) $52.5 \%, \mathrm{NO}_{3}{ }^{-}$ $43.6 \%$, and $\mathrm{NH}_{4}{ }^{+} 51.6 \%$, respectively. For different $\mathrm{N}$ forms, each structure had a different retention efficiency. Dry ponds and stone dams were more effective for particulate $\mathrm{N}$, while the vegetated filter strip and riparian buffer zone were more effective for dissolved $\mathrm{N}$ forms. Dry ponds were the reliable structures for controlling sediment and $\mathrm{N}$ export in this watershed, while the retention efficiency of pollutants by the roadside grassed ditch was highly unreliable. The hydrological control by this system of flow velocity and runoff volume, which were the two key factors determining the export load of pollutants, was one of the main mechanisms in the retention of sediment and $\mathrm{N}$. The use of diversified agricultural landscape buffer structures is an effective way to reduce the discharge of valuable nutrients and thus pollution of downstream waterbodies.
\end{abstract}

(C) 2004 Elsevier B.V. All rights reserved.

Keywords: Landscape structure; Nitrogen; Retention; Water quality; Agricultural watershed

\footnotetext{
* Corresponding author. Tel.: +86106284 9307; fax: +861062923543.

E-mail address: cqyin@mail.rcees.ac.cn (C.Q. Yin).
}

\section{Introduction}

Fluxes of sediment and nutrients in agricultural landscapes are receiving more attention due to their important role in determining regional water quality. High levels of nutrients and sediment in water can 
pose significant human and ecological risks and the concomitant eutrophication may cause various detrimental results, as many studies have shown (Kronvang et al., 1993; Ator and Ferrari, 1997; Diederik et al., 1998). To overcome nitrogen $(\mathrm{N})$ limitation in the terrestrial agroecosystem, large quantities of $\mathrm{N}$ have been applied, resulting in accelerated $\mathrm{N}$ loss and its saturation of aquatic ecosystems (Smil, 1991; Vitousek and Howarth, 1991; Ma, 1997). Discharges abundant in $\mathrm{N}$ may accelerate the eutrophication of reservoirs and lakes. Adverse effects may include the formation of nitrosoamines, toxicity in aquatic life and a dramatic increase in water treatment costs. Controlling $\mathrm{N}$ losses has increasingly become an important objective in water quality management (Leu et al., 1996). Flow of sediment and $\mathrm{N}$ discharged by an agricultural watershed in North China was studied in detail in this research.

One of the most important pathways by which $\mathrm{N}$ enters waterbodies is via the diffuse runoff from agricultural lands during rainfall events (Howarth, 1988; Puckett, 1995; Hessen et al., 1997; Carpenter et al., 1998; Downing et al., 1999). Spatial patterns within the landscapes, such as the location, distribution and proportions of watershed areas can crucially affect $\mathrm{N}$ exports (Jordan et al., 1993; Hunsaker and Levine, 1995; Hill, 1996; Creed and Band, 1998; Hillbricht-Ilkowska et al., 2000). Landscape elements modify movements of $\mathrm{N}$ discharge to waterbodies (Forman and Gordon, 1986; Turner, 1987; Ryszkowski, 1989). Thus, the control of $\mathrm{N}$ export requires a profound understanding of the structure and function of the landscape system, especially the various processes taking place on pathways (Tim et al., 1995).

Watersheds are complex landscapes containing multiple potential sources or sinks of $\mathrm{N}$. There is increasing interest in providing various traps or sink structures (wetlands, buffer zones, etc.) on water pathways to slow down transportation and cycling of nutrients within agricultural watersheds (Dickey and Vanderholm, 1981; Cooper et al., 1987; Pomogyi, 1993; Fleischer et al., 1994; Leonardson et al., 1994; Kuusemets and Mander, 2002). In most of the previous studies, however, the focus was on the assessment of the effectiveness of single sink structures in the reduction of sediment and $\mathrm{N}$ load under controlled field-plot experiments. Relatively few studies about relationships between $\mathrm{N}$ fluxes and diversified sink landscape structures under real world conditions have been conducted (Daniels and Gilliam, 1996; UusiKämppä et al., 2000; Hillbricht-Ilkowska et al., 2000).

In South China, studies have proved that distributing the multipond system in the agricultural landscape efficiently controls the export of nutrients from the headwater watershed (Yin et al., 1993; Yan et al., 1998). But in North China, the climate is relatively dry limiting the application of the ponds system. The agricultural landscape in North China is a complex arrangement of geologic features, different soil types, vegetation and alterations due to different kinds of land use. Many natural or artificial buffer/detention sink landscapes (field edges, road borders, abandoned fishponds, depressions, etc.) have been created as a result of human alterations (intensive cultivation, the construction of roads, fish farming, etc.) and natural events. It would seem likely that these buffer/detention landscapes have some effect on nutrient flow. Thus, there is a need to identify hydrological and ecological processes taking place in the material transporting pathways and the dominant controlling mechanisms which influence nutrient transport process. As a result, efficient measures can be taken to reduce the risk of excessive nutrients being exported from the contributing basins. Furthermore, investigating the possible effects of landscape structures on the transportation of $\mathrm{N}$ flow is essential for downstream water quality management.

The objectives of this study were to explicate the hydrological and ecological processes of $\mathrm{N}$ transportation in a typical agricultural landscape of North China and to compare the stability and efficiency of different types of landscape buffer structures.

\section{Materials and methods}

\subsection{The study area}

Yuqiao Reservoir is the source of drinking water for Tianjin, the third largest city of China. The Taohuasi watershed is located on the north bank of the reservoir with an area of 248.9 ha (Fig. 1a). The topography of the watershed shows a transition pattern of mountainous area to plain from north to south with an elevation from 310 to $17 \mathrm{~m}$ above Bohai Sea level and with a steep $\left(>25^{\circ}\right)$ to gentle $\left(<5^{\circ}\right)$ slope. The relief is strongly 
differentiated and there are many ridges, hills and depressions accompanied by cliffs, channels and ephemeral stream valleys. Because of the rolling topography, the soils are susceptible to erosion. Soil in the watershed is classified as Luvisol (FAO, 1990). Three types of soil-Braunerde, Cinnamon and Aqualf strip distribute from north to south. Cinnamon soil occupies most of the area of the watershed and covers the chief agricultural area. The soil texture can be divided into sandy loam and heavy loam. The major crops are wheat, corn, rice and peanuts. The main forms of land use in the Taohuasi watershed are hilly land and cropland occupying 49.3 and $29.6 \%$ of the total area, respectively. Other land uses make up about $21.1 \%$ (Fig. 1b). There are 288 residents in the Taohuasi village and they raise about 6000 chickens, 80 pigs, 100 goats, 20 cows and 50 deer. Most of the waste produced by the poultry and livestock is typically piled openly on the ground before being applied to the orchard and farmland. The farmers use dry toilets and most solid wastes are used as manure after fermentation. There are no wastewater treatment facilities. Most waste is spread openly on the ground. When it rains, the polluted runoff formed as a result of drainage through the piled manure, the courtyards and the streets flows into an ephemeral stream near the village and is transported downstream. Farmers apply compound fertilizer and urea to crops as the basic and supplement nutrients. The amount applied is $400 \mathrm{~kg} \mathrm{Nha}^{-1}$ by top-dressing. During rainfall events, the nutrients are picked up by surface runoff and transported to the stream channel nearby.

\subsection{Watershed climate and flow characteristics}

The climate of the watershed is characterized by warm summers and cold winters. The mean annual temperature is $11.5^{\circ} \mathrm{C}$. Long-term average precipitation is $748.5 \mathrm{~mm}$ and $80 \%$ of the rainfall occurs from June to August. Water only flows in the stream channel during rainfall events in which surface runoff is generated. There is no base flow in the stream channel. This watershed responds rapidly to rainfall and surface flow occurs for less than $24 \mathrm{~h}$. Characteristics of rainfall events in this watershed are high intensity and short duration. The main runoff yield pattern is infiltration excess runoff pattern. Surface runoff initiates as long as the rainfall intensity exceeds the infiltration capacity of soil and mostly in the early stage during a rainfall event.
Thus, both the occurring and the disappearing of surface runoff are rapid. In short time, the pollutants could be transported by the surface runoff to the waterbodies downstream. For research proposes, precipitation was monitored at an official meteorologic station of Yuqiao Reservoir just adjacent to Taohuasi Watershed. During 2001-2003, 21 rainfall-runoff events were monitored (Table 1). These rainfall-runoff events included 5 continuous runoff events and 16 discontinuous runoff events. The duration of water flow in the stream channel and outflow of each structure depended on the characteristics of the respective rainfall event.

\subsection{Sampling method and sample analysis}

The investigation was conducted from autumn 2001 to autumn 2003. In this research, we chose four stone dams (SDs), a roadside grassed ditch (RGD), a vegetated filter strip (VFS), two dry ponds (DPs) and a riparian buffer zone (RBZ) to study. These structures were selected and not any of others because of their well hydrological continuity from the south of the hilly land to the outlet of the watershed and being looked upon as a combined landscape structure system dealing with the polluted runoff from various land uses near the stream channel. Four stone dams were close to the village and could receive the polluted runoff from village and orchard during the period of rainfall events. A series of sampling sites was installed from inlet to outlet of each buffer structure to study detailed processes during $\mathrm{N}$ flow crossing. These sampling sites included 28 sites to monitor surface flow in the stream channel and 5 of tributary flow from different land uses along the stream channel. Runoff samples were taken manually and the sampling work was accomplished with the help of several farmers who had sampling experience. During a rainfall-runoff event, the sampling volunteers were divided into groups of three to five, according to the event size. The time of sampling on the hydrograph was recorded. We tried our best to keep the same series of samples being taken at the same time.

The discharge of runoff was continuously measured through V-notch concrete flumes which were all of $120^{\circ}$ notches, while water velocity was measured in two ways. When there was low water depth or dense vegetation, the use of a kinemometer was restricted and the flow velocity estimation was accomplished by 


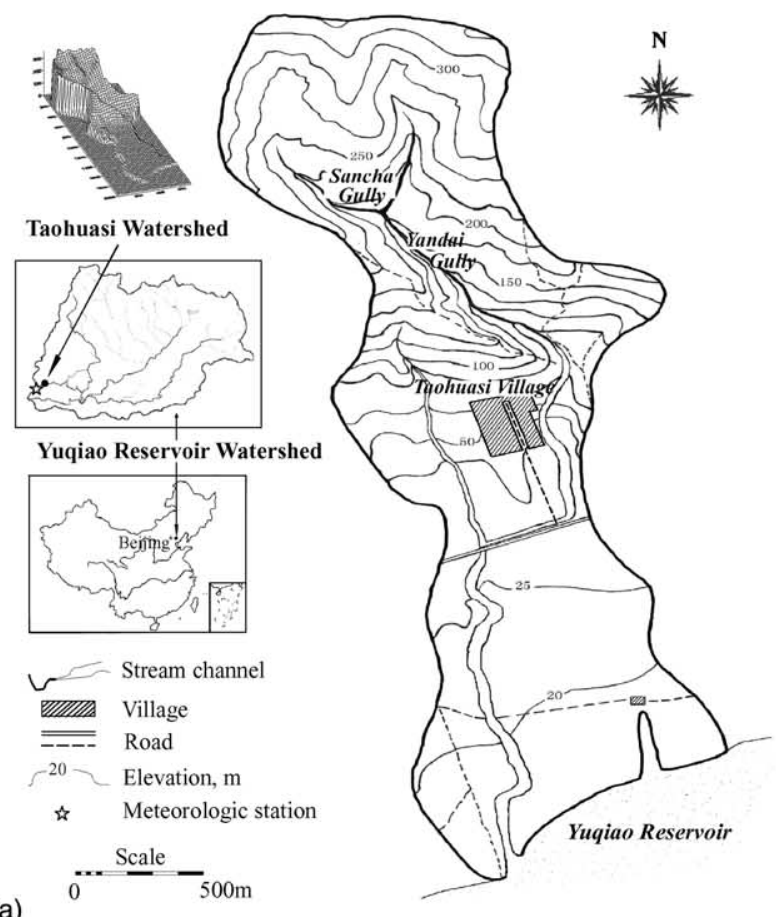

(a)

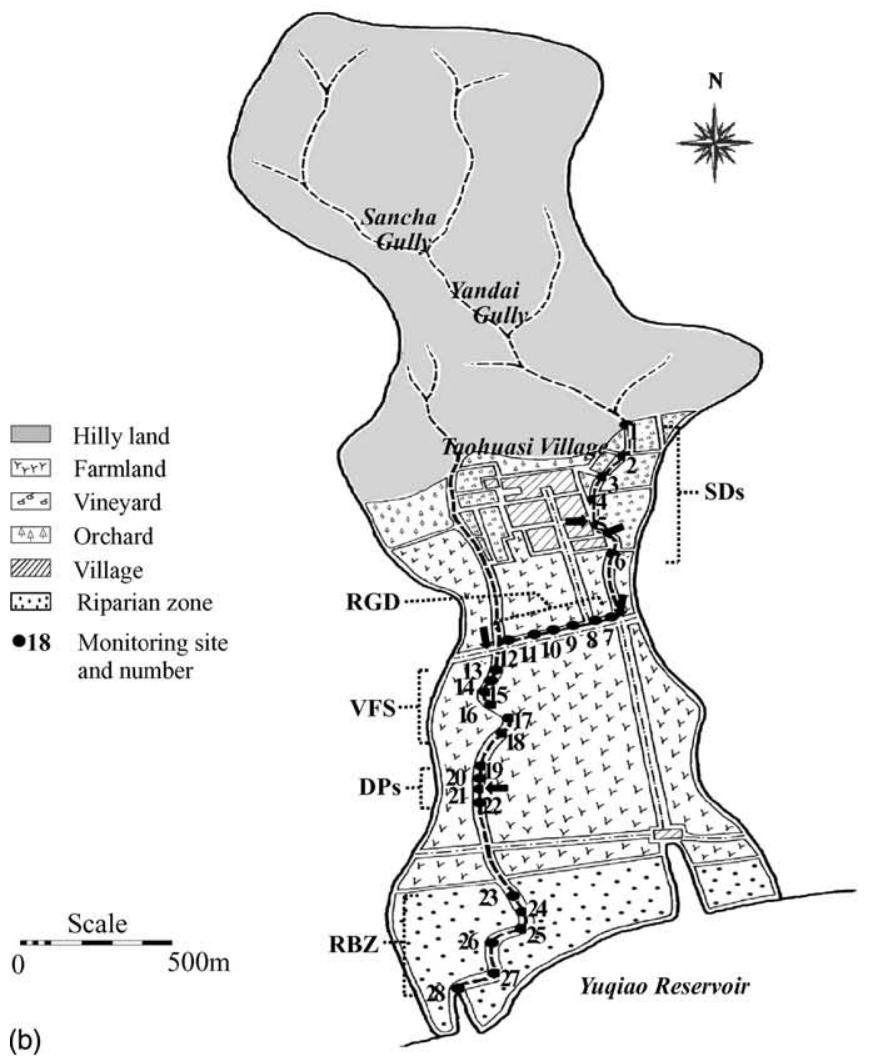


Table 1

Characteristics of 21 rainfall-runoff events in Taohuasi watershed during 2002 and 2003

\begin{tabular}{|c|c|c|c|c|c|}
\hline $\begin{array}{l}\text { Date of } \\
\text { rainfall event }\end{array}$ & $\begin{array}{l}\text { Precipitation } \\
(\mathrm{mm})\end{array}$ & $\begin{array}{l}\text { Rainfall intensity } \\
\left(\mathrm{mm} \mathrm{h}^{-1}\right)\end{array}$ & $\begin{array}{l}\text { Date of } \\
\text { rainfall event }\end{array}$ & $\begin{array}{l}\text { Precipitation } \\
(\mathrm{mm})\end{array}$ & $\begin{array}{l}\text { Rainfall intensity } \\
\left(\mathrm{mm} \mathrm{h}^{-1}\right)\end{array}$ \\
\hline 19 June 2002 & 14.7 & 4.90 & 28 June 2003 & 15.2 & 5.07 \\
\hline 23 June 2002 & 18.6 & 4.65 & 27 July 2003 & 14.8 & 4.93 \\
\hline 25 June 2002 & 11.5 & 1.15 & 5 August 2003 & $53.9^{\mathrm{a}}$ & 21.56 \\
\hline 2 July 2002 & 9.3 & 4.69 & 6 August 2003 & 12.2 & 4.40 \\
\hline 16 July 2002 & 26.5 & 20.38 & 15 August 2003 & 10.7 & 9.73 \\
\hline 3 August 2002 & 5.9 & 5.67 & 26 August 2003 & 12.3 & 8.20 \\
\hline 4 August 2002 & 22.4 & 6.13 & 28 August 2003 & $63.5^{\mathrm{a}}$ & 14.11 \\
\hline 26 August 2002 & $43.4^{\mathrm{a}}$ & 8.68 & 4 September 2003 & 13.6 & 6.80 \\
\hline 5 June 2003 & 11.1 & 7.10 & 7 September 2003 & 8.1 & 4.05 \\
\hline 9 June 2003 & 17.7 & 3.97 & 8 September 2003 & $38.3^{\mathrm{a}}$ & 15.32 \\
\hline 22 June 2003 & $62.9^{\mathrm{a}}$ & 15.21 & & & \\
\hline
\end{tabular}

\footnotetext{
${ }^{\mathrm{a}}$ Indicates continuous runoff events.
}

measuring the tracer velocity of small plastic buoys. When the water depth was deep enough, a kinemometer could be used. There was a V-notch weir in the inlet and outlet of each structure. Flow-proportional samples (4-10 subsamples/runoff event) were taken at each site.

Samples of runoff water were taken in plastic bottles and mid-depth of runoff water at the monitoring sites when surface runoff was generated in a rainfall event. Water samples were taken at $10 \mathrm{~min}$ or longer intervals depending on the duration of the event. After sampling, $250 \mathrm{ml}$ aliquots were filtered by pre-weighed $0.45 \mu \mathrm{m}$ Millipore filters. Filters were then dried and re-weighed to quantify total suspended solid (TSS). The filtrate was reserved for measuring dissolved constituents of total dissolved nitrogen (TDN), $\mathrm{NO}_{3}{ }^{-}, \mathrm{NH}_{4}{ }^{+}$and the unfiltered samples were used for measuring total nitrogen (TN). The filtered and unfiltered water samples were stored in a refrigerator at $4{ }^{\circ} \mathrm{C}$ and analyzed at the State Key Laboratory of Environmental Aquatic Chemistry within $48 \mathrm{~h}$ after sampling. All analyses were done according to Standard Methods (APHA, 1985).

\subsection{Calculation of sediment and $N$ retention}

The retention efficiency of sediment and $\mathrm{N}$ for each buffer structure and for the whole system was calculated from flow-weighted mean concentration and runoff volume when it entered and left the structure. Pollutants carried by tributaries were incorporated into the total import load of the corresponding structure to calculate the retention efficiency. The retention rate of the structure (or the system) was calculated using the following formula:

$$
\begin{aligned}
& M_{\mathrm{PI}}=\sum Q_{\mathrm{PI} i} C_{\mathrm{PI} i} \\
& M_{\mathrm{PO}}=\sum Q_{\mathrm{PO} i} C_{\mathrm{PO} i} \\
& R=\left(1-\frac{M_{\mathrm{PO}}}{M_{\mathrm{PI}}}\right) \times 100 \%
\end{aligned}
$$

where $Q_{\mathrm{PI} i}$ and $Q_{\mathrm{PO} i}$ are inflow and outflow volume of the structure $\left(\mathrm{m}^{3}\right), C_{\mathrm{PI} i}$ and $C_{\mathrm{PO} i}$ the flow-weighted mean concentrations in inflow and outflow of the structure $\left(\mathrm{kg} \mathrm{m}^{-3}\right), M_{\mathrm{PI} i}$ and $M_{\mathrm{PO} i}$ the total pollutants mass in inflow and outflow of the structure $(\mathrm{kg}), i$ from 1 to 5 , are landscape structure number (1, SDs; 2, RGD; 3, VFS; 4, DPs; 5, RBZ), $R$ is the retention rate of pollutants.

Data from 21 rainfall-runoff events were used in statistical analyses. Analyses of variance were performed according to the SAS procedure (SAS Institute, 1996).

Fig. 1. (a) The geographical location of Yuqiao Reservoir and Taohuasi experimental watershed. (b) Spatial distribution of land use and monitoring sites along the stream channel in Taohuasi watershed. Monitoring sites include: stone dams (SDs), Nos. 1-6; roadside grassed ditch (RGD), Nos. 7-12; vegetated filter strip (VFS), Nos. 13-18; dry ponds (DPs), Nos. 19-22; riparian buffer zone (RBZ), Nos. 23-28. Black arrows represent temporary tributary flow from various land uses during rainfall events. 


\section{Results and discussion}

\subsection{Diversified landscape buffer structures}

An ephemeral stream extends in the experimental watershed, crossing through a series of agricultural land uses. We found that there are several different types of landscape buffer structure along this headwater stream. They are stone dams, a roadside grassed ditch, a vegetated filter strips, dry ponds and a riparian buffer zone. These structures are described as follows.

In the upstream area, a series of stone dams are ranked in the channel. Stone dams are small dams made of rocks constructed across the stream channel. In the 1960s, these stone dams were built to reduce channel erosion. A series of stone dams constructed along the stream channel transform a comparatively steep slope into a stair-stepped gentle slope. Although their primary purpose is to reduce channel erosion, stone dams also retain sediment and hence act as filters. Concentrated flow can be converted into sheet flow. Through slowing runoff velocity and forming detention conditions, sediments in surface runoff are deposited at the bottom of these dams, preventing transportation downstream. We found particle nutrients carried by surface runoff from the village nearby were also retained by these dams. In addition, the walnut trees grown by farmers on the alluvial soil improves the buffer capacity of these dams further.

A road crosses through the middle part of the watershed from east to west. Roadside ditches are a common feature of the road section, conveying water parallel to the driving lanes. The soil surface of these ditches is covered with annual vegetation from spring to autumn (mainly aggressive weedy species), including Lamb's-quarters (Chenopodium aibum L.) and common plantain (Plantago major L.), among other species. Although the ditches are designed simply as drainage ways, they can also perform as water quality structures as a result of their capacity for hydraulic resistance and filtration. When surface runoff flows through the ditch, the flow is impeded due to roughness caused by vegetation. The infiltration coefficient is improved because of the good physical structure of the soil formed by roots. The pollutants are partly removed through these functions. However, due to the lack of effective management measures, the growing condition of the vegetation is poor and trash sometimes accumulates at the bottom of the ditch. This influences the purification of polluted runoff.

To the south of the road, the stream channel crosses a large area of cropland. Abundant vegetation growing in the channel forms a long natural vegetated filter strip. Vegetation is comprised of sage (Salvia officinalis L.) and wormwood (Artemisia absinthium L.). The vegetated filter strip located in a relatively gentle relief is in a natural condition, and is not subject to human disturbance. As the results of many studies have shown, vegetated filter strips retain nutrients by reducing the runoff velocity, filtration, sedimentation and infiltration, etc. (Dickey and Vanderholm, 1981; Dillaha et al., 1988, 1989; Vought et al., 1995). The fine roots of the plants, which are concentrated on or near the surface and the microbial communities on the soil surface, litter and above-ground plant parts are able to assimilate dissolved nutrients from surface water (Peterjohn and Correll, 1984).

There are many dry ponds distributed over the village, cropland, stream channel and reservoir bank. These ponds were artificially made for different purposes, including fish farming, irrigation and washing etc. They can temporarily store some of the runoff following a storm. The storage capacity depends on their volume. The primary retention mechanism of nutrients is sedimentation which results from the stilling effect of detention, allowing heavier sediments to settle by gravity, leaving a suspension. The longer the detention time within the ponds, the greater the amount of nutrients that will be retained. The pond overflows only when the water volume is in excess of its storage capacity. The two ponds selected as part of our research project are located in the downstream area.

Abundant grasses cover the water table fluctuation zones of reservoir and this area can be regarded as a kind of buffer zone or land-water ecotone. When polluted runoff enters this zone, the pollutants can be retained through various biological and chemical reactions. These retention mechanisms include sedimentation, uptake by vegetation and denitrification (Cooper et al., 1987; Warwick and Hill, 1988; Vought et al., 1994; Tabacchi et al., 2000; Sabater et al., 2003).

These landscape structures are formed under different hydrogeological conditions or artificially 
Table 2

Characteristics of diversified sink structures distributed along the ephemeral stream upslope to the downslope of the experimental watershed

\begin{tabular}{llllcccc}
\hline Type $^{\mathrm{a}}$ & $\begin{array}{l}\text { Constitutive } \\
\text { parts }^{\mathrm{b}}\end{array}$ & Elevation $(\mathrm{m})$ & $\begin{array}{l}\text { Average height } \\
\text { or depth }(\mathrm{m})\end{array}$ & Length $^{\mathrm{c}}(\mathrm{m})$ & Width $(\mathrm{m})^{\text {Area }\left(\mathrm{m}^{2}\right)}$ & $\begin{array}{l}\text { Adjacent } \\
\text { land use }\end{array}$ \\
\hline SDs & Dam 1 & 48.3 & 1.2 & 63.5 & 16.0 & 304.0 & Hilly land \\
& Dam 2 & 47.2 & 0.9 & 39.0 & 14.0 & 546.0 & Hilly land, village \\
& Dam 3 & 46.0 & 1.1 & 59.0 & 21.0 & $1.24 \times 10^{3}$ & Hilly land, village \\
& Dam 4 & 40.6 & 0.8 & 86.0 & 11.0 & 946.0 & Village, orchard \\
RGD & - & $26.2-27.1$ & 0.4 & 260.0 & 2.0 & 520.0 & Road, cropland \\
VFS & - & $24.3-25.4$ & - & 182.0 & $7.0-7.5$ & $1.27 \times 10^{3}$ & Cropland \\
DPs & Pond 1 & 24.1 & 0.9 & 6.3 & - & 31.5 & Cropland \\
& Pond 2 & 22.6 & 1.2 & 23.5 & - & 212.0 & Cropland \\
RBZ & - & $16.8-17.3$ & - & 302.0 & - & $2.871 \times 10^{5}$ & Cropland, reservoir \\
\hline
\end{tabular}

a SDs, RGD, VFS, DPs, and RBZ are abbreviations of stone dams, roadside grassed ditch, vegetated filter strip, dry ponds, and riparian buffer zone, respectively.

b Stone dams and dry ponds are composed of four dams and two ponds, respectively.

${ }^{c}$ Length refers to distance from inlet to outlet of the structure.

created during intensive cultivation, road construction, fish farming, etc. Their characteristics vary (Table 2) and deeply influence their main retention mechanisms of water and pollutants. Between these structures, there are no other buffer structures in the stream channel. From the stone dams near the Taohuasi village upstream to the buffer zones by the reservoir downstream, five types of structures (subsystems) constitute the diversified sink landscape structures system which controls the flow of $\mathrm{N}$ in the surface pathway (Fig. 2).

\section{2. $N$ concentration variation in the flowpath}

The concentrations of sediments and $\mathrm{N}$ pollutants were greatly affected by the landscape buffer structures during the transportation of the polluted runoff in the flow pathway (Fig. 3). In the Taohuasi watershed, there are two types of surface runoff during a rainfall-runoff event: continuous runoff and discontinuous runoff (Shan et al., 2002). Continuous flow is generated only during a heavy rainfall event, in which water flow is transported from the upstream to

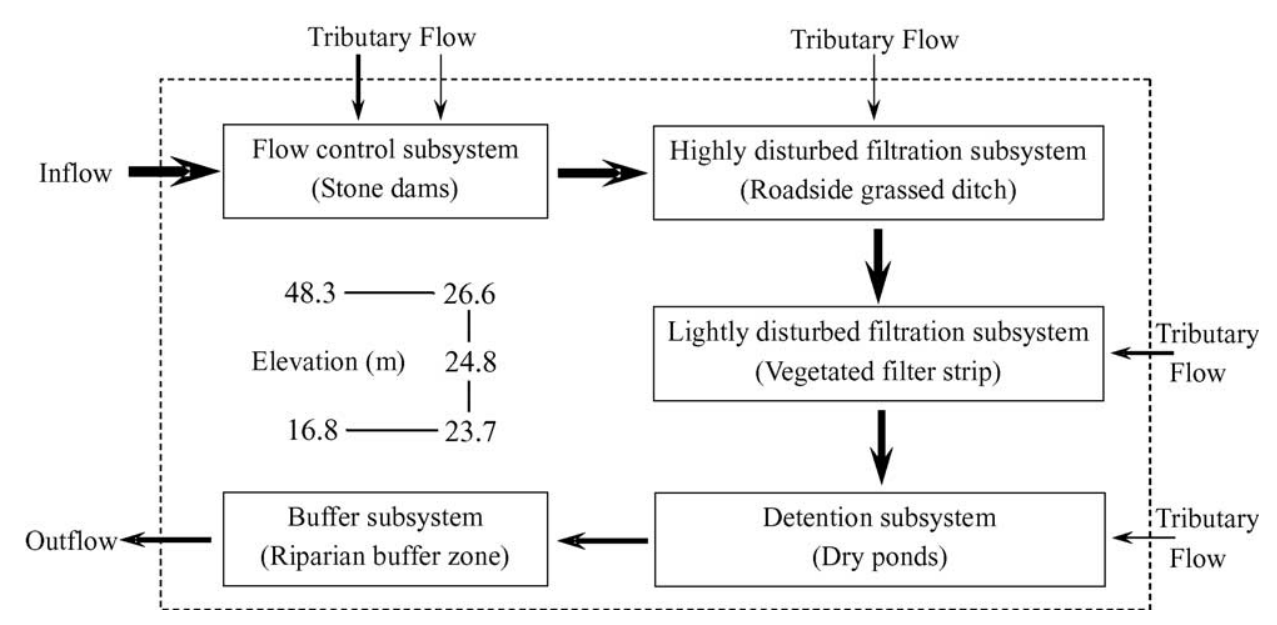

Fig. 2. Sketch map of diversified landscape buffer structures system and its five subsystems in the experimental watershed. Thickness of arrows represents the volume of water flow. 

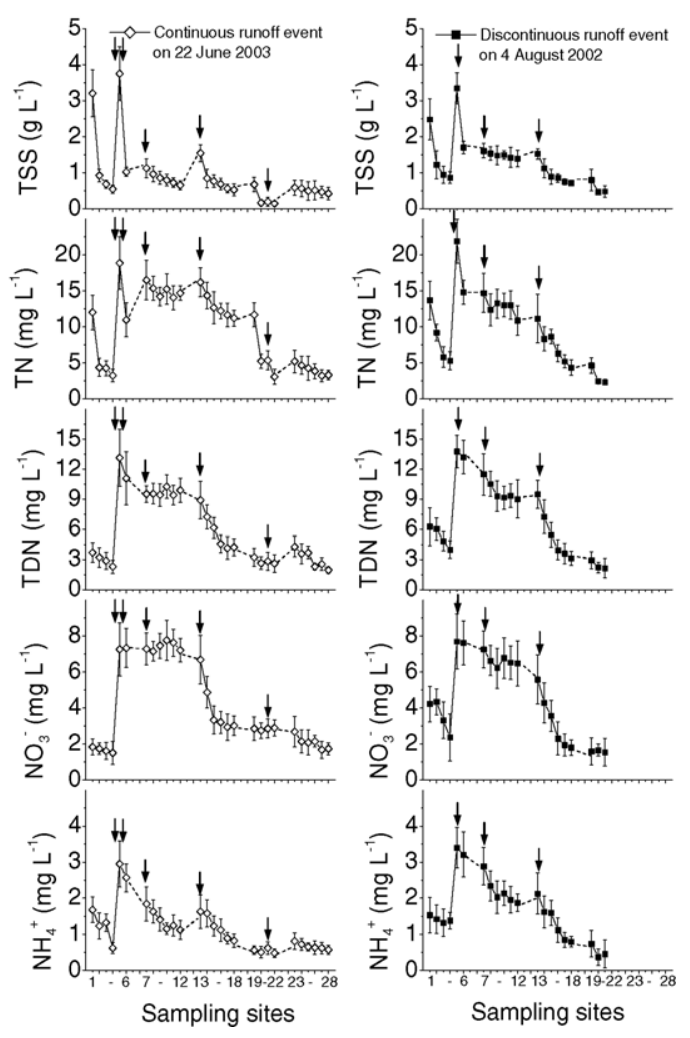

Fig. 3. The spatial variation of TSS and N concentration in surface runoff along the flow pathway during the continuous runoff event on 22 June 2003 and the discontinuous runoff event on 4 August 2002. The dashed line stands for runoff transporting in the stream channel between two structures. Black arrows represent temporary tributary flow from various land uses during rainfall events. Vertical bars show standard errors.

the outlet of the watershed. Discontinuous flow is usually generated during a gentle rainfall, in which water flow is divided into several segments with little or no outflow exported from the watershed. Two typical rainfall events, precipitation $62.9 \mathrm{~mm}$ on 22 June 2003 and $22.4 \mathrm{~mm}$ on 4 August 2002, which are representative of the two types of runoff events, were selected to describe the processes that occur during the continuous and discontinuous runoff events, respectively.

In both types of events, the concentration of sediments and $\mathrm{N}$ pollutants in the flowpath increased with the input of tributaries from various agricultural land uses (especially in village area) and gradually decreased as the runoff passed through each structure.
During the continuous runoff event on 22 June 2003 (Fig. 3), the concentrations of TSS, TN, TDN, $\mathrm{NO}_{3}{ }^{-}$, $\mathrm{NH}_{4}{ }^{+}$in the inflow of the whole system were $3.20 \mathrm{~g} \mathrm{~L}^{-1}, \quad 12.02,3.71, \quad 1.84$ and $1.68 \mathrm{mg} \mathrm{L}^{-1}$, respectively. But when the flow was mixed with tributary flow from the village, the concentrations of TSS, TN, TDN, $\mathrm{NO}_{3}{ }^{-}, \mathrm{NH}_{4}{ }^{+}$were increased to $3.75 \mathrm{~g} \mathrm{~L}^{-1}, 18.86,13.13,7.26$ and $2.95 \mathrm{mg} \mathrm{L}^{-1}$, respectively. After passing through the four stone dams, particulate materials were largely retained. But the proportion of dissolved $\mathrm{N}$ pollutants (TDN, $\mathrm{NO}_{3}{ }^{-}$, $\mathrm{NH}_{4}{ }^{+}$) retained was small. This perhaps attributed to the low uptake quantity of $\mathrm{N}$ and low infiltration. TSS in the inflow and the outflow of roadside grassed ditch was 1.08 and $0.65 \mathrm{~g} \mathrm{~L}^{-1}$, respectively. While for $\mathrm{N}$, the concentration presented a fluctuation pattern in this section. The latter may be the result of, for example, the lack of effective management measures, occasional destructive events and the accumulation of trash at the bottom of the ditch. Comparatively, the concentration of sediment and $\mathrm{N}$ pollutants decreased gradually as the runoff was transported in the vegetated filter strip. This strip was in a natural, less disturbed state. The vegetated filter strip effectively reduced the concentration of various forms of $\mathrm{N}$. During polluted runoff transportation through dry ponds and the riparian buffer zone, the concentration of sediment and $\mathrm{N}$ was reduced further. The reduction of dissolved $\mathrm{N}$ pollutants (TDN, $\mathrm{NO}_{3}{ }^{-}, \mathrm{NH}_{4}{ }^{+}$) was not as significant as that of TSS and TN in the ponds zone. This meant that the dry ponds were more effective in the reduction of particulate pollutants than dissolved forms. The concentration of pollutants reached $0.42 \mathrm{~g} \mathrm{~L}^{-1}$ of TSS, $3.32 \mathrm{mg} \mathrm{L}^{-1}$ of TN, $1.93 \mathrm{mg} \mathrm{L}^{-1}$ 1 of TDN, $1.74 \mathrm{mg} \mathrm{L}^{-1}$ of $\mathrm{NO}_{3}{ }^{-}$and $0.57 \mathrm{mg} \mathrm{L}^{-1}$ of $\mathrm{NH}_{4}{ }^{+}$at the outlet of the watershed, respectively.

During the discontinuous runoff event on 4 August 2002, the transportation process of water and pollutants was intermittent and that volume of runoff was relatively small, although the flow patterns were similar (Fig. 3). However, there was no water and pollutant exported from the watershed during the discontinuous runoff events. The reduction of TSS and $\mathrm{N}$ concentration was more rapid. Under both continuous and discontinuous hydrological conditions, the buffer structures system effectively reduced the concentration of TSS and N in surface runoff. 
Table 3

Retention rate (mean \pm standard deviation) of water and pollutants of the buffer structures system during different runoff events

\begin{tabular}{|c|c|c|c|c|c|c|c|}
\hline & \multicolumn{5}{|l|}{ System input } & \multirow[t]{2}{*}{ System output } & \multirow[t]{2}{*}{ Retention rate $(\%)$} \\
\hline & $\mathrm{SH}^{\mathrm{a}}$ & SV & SO & $\mathrm{SC}$ & Total & & \\
\hline \multicolumn{8}{|c|}{ Continuous runoff event on 22 June 2003} \\
\hline Water $\left(\mathrm{m}^{3}\right)$ & $724.3 \pm 102.5$ & $256.3 \pm 42.6$ & $26.2 \pm 4.5$ & $112.4 \pm 14.5$ & $1119.2 \pm 123.5$ & $556.9 \pm 49.6$ & $50.2 \pm 7.3$ \\
\hline TSS $(\mathrm{kg})$ & $2635.2 \pm 309.6$ & $902.4 \pm 83.5$ & $9.3 \pm 1.3$ & $62.5 \pm 3.9$ & $3609.4 \pm 481.1$ & $986.3 \pm 106.9$ & $72.7 \pm 9.2$ \\
\hline $\mathrm{TN}(\mathrm{kg})$ & $2.635 \pm 0.324$ & $4.589 \pm 0.336$ & $0.402 \pm 0.052$ & $0.811 \pm 0.102$ & $8.437 \pm 0.658$ & $2.859 \pm 0.354$ & $66.1 \pm 7.5$ \\
\hline TDN (kg) & $1.524 \pm 0.314$ & $2.986 \pm 0.326$ & $0.287 \pm 0.036$ & $0.532 \pm 0.063$ & $5.329 \pm 0.521$ & $2.531 \pm 0.196$ & $52.5 \pm 6.8$ \\
\hline $\mathrm{NO}_{3}^{-}(\mathrm{kg})$ & $0.745 \pm 0.152$ & $1.427 \pm 0.127$ & $0.124 \pm 0.027$ & $0.236 \pm 0.057$ & $2.532 \pm 0.238$ & $1.427 \pm 0.186$ & $43.6 \pm 8.9$ \\
\hline $\mathrm{NH}_{4}^{+}(\mathrm{kg})$ & $0.425 \pm 0.026$ & $1.114 \pm 0.086$ & $0.106 \pm 0.023$ & $0.207 \pm 0.019$ & $1.852 \pm 0.148$ & $0.896 \pm 0.075$ & $51.6 \pm 4.7$ \\
\hline \multicolumn{8}{|c|}{ Discontinuous runoff event on 4 August 2002} \\
\hline Water $\left(\mathrm{m}^{3}\right)$ & $312.4 \pm 44.6$ & $188.6 \pm 32.6$ & 0 & $74.1 \pm 10.1$ & $575.1 \pm 48.6$ & 0 & 100 \\
\hline TSS $(\mathrm{kg})$ & $458.3 \pm 70.3$ & $455.2 \pm 30.4$ & 0 & $52.0 \pm 6.3$ & $965.5 \pm 101.3$ & 0 & 100 \\
\hline $\mathrm{TN}(\mathrm{kg})$ & $1.236 \pm 0.147$ & $3.024 \pm 0.298$ & 0 & $0.524 \pm 0.632$ & $4.784 \pm 0.369$ & 0 & 100 \\
\hline TDN (kg) & $0.853 \pm 0.125$ & $1.457 \pm 0.122$ & 0 & $0.356 \pm 0.245$ & $2.666 \pm 0.325$ & 0 & 100 \\
\hline $\mathrm{NO}_{3}^{-}(\mathrm{kg})$ & $0.402 \pm 0.038$ & $0.855 \pm 0.085$ & 0 & $0.198 \pm 0.165$ & $1.455 \pm 0.187$ & 0 & 100 \\
\hline $\mathrm{NH}_{4}{ }^{+}(\mathrm{kg})$ & $0.211 \pm 0.026$ & $0.489 \pm 0.326$ & 0 & $0.103 \pm 0.024$ & $0.803 \pm 0.096$ & 0 & 100 \\
\hline
\end{tabular}

${ }^{\text {a }} \mathrm{SH}$, surface runoff from hilly land; SV, surface runoff from village; SO, surface runoff from orchard; SC, surface runoff from cropland.

\subsection{Sediment and $N$ retention}

\subsubsection{Retention efficiency of the buffer structure system}

The diversified buffer structures effectively reduced the loads of sediment and $\mathrm{N}$ pollutants exported from the watershed although the retention efficiency differed under different hydrological conditions. During the continuous runoff event on 22 June 2003, the total surface runoff volume generated from the Taohuasi watershed was about $1119.2 \mathrm{~m}^{3}$ and the volume exported was about $556.9 \mathrm{~m}^{3}$. Most of the balance was intercepted by these buffer structures. The retention rate of water by the whole system was $50.2 \%$. The capacity of these buffer structures is well below the theoretical maximum. This is possibly because: (i) Due to the problem of filling up by alluvial soil, the capacity of stone dams was decreased to a great extent compared with the design standards. (ii) The dams and ponds remain partly full between rainfall events. (iii) Four stone dams studied in this research had some rifts in the constituting rocks resulting in penetrating of water and decrease of storage capacity. Thus, the capacity of the system would be improved further with some suitable management measures (i.e. dredging, irrigation with storage water, etc.). The input loads of TSS, TN, TDN, $\mathrm{NO}_{3}{ }^{-}$and $\mathrm{NH}_{4}{ }^{+}$by the surface runoff from various sources were $3609.4,8.437,5.329,2.532$ and $1.852 \mathrm{~kg}$, respectively, whereas the exports were $986.3,2.859,2.531,1.427$ and $0.896 \mathrm{~kg}$, respectively (Table 3). The retention rates were $72.7 \%$ of TSS, $66.1 \%$ of TN, $52.5 \%$ of TDN, $43.6 \%$ of $\mathrm{NO}_{3}{ }^{-}, 51.6 \%$ of $\mathrm{NH}_{4}{ }^{+}$, respectively.

During the discontinuous runoff events on 4 August 2002 , the total input of water, TSS, TN, TDN, $\mathrm{NO}_{3}{ }^{-}$ and $\mathrm{NH}_{4}{ }^{+}$from various sources were $575.1 \mathrm{~m}^{3}, 965.5$, $4.784,2.666,1.455$ and $0.803 \mathrm{~kg}$, respectively. No surface water was exported from the outlet of the watershed representing retention rates of $100 \%$ (Table 3). Under different hydrological conditions, the buffer structures system was all capable of markedly reducing the export load of sediment and $\mathrm{N}$ from the watershed.

Although local soils are susceptible to erosion, the erosion (TSS) loss and the volume of surface runoff during a rainfall event was relatively low in the experimental watershed. This was possibly because: (i) Under the infiltration excess runoff pattern in North China, runoff volume directly depends on rainfall intensity and does not occur at sufficiently low intensities. High intensity of rainfall is mainly in the early stage of a rainfall event in North China and this period is short. Thus, most of rainwater infiltrates the soil during a rainfall event and the runoff volume is relatively small compared to the rainfall depth. 
Table 4

Retention rate (mean \pm standard deviation, $\%$ ) of water and pollutants of single structure during different types of rainfall-runoff events

\begin{tabular}{|c|c|c|c|c|c|c|c|c|c|c|}
\hline & \multicolumn{5}{|c|}{ Continuous event on 22 June 2003} & \multicolumn{5}{|c|}{ Discontinuous event on 4 August 2002} \\
\hline & $\mathrm{SDs}^{\mathrm{a}}$ & RGD & VFS & DPs & $\mathrm{RBZ}$ & SDs & RGD & VFS & DPs & RBZ \\
\hline Water & $6.7 \pm 1.2$ & $8.0 \pm 2.6$ & $10.5 \pm 2.3$ & $31.8 \pm 4.2$ & $3.7 \pm 0.8$ & $36.3 \pm 5.2$ & $39.6 \pm 7.9$ & $68.7 \pm 7.5$ & 100.0 & $-b$ \\
\hline TSS & $40.1 \pm 6.8$ & $6.5 \pm 2.1$ & $18.0 \pm 3.7$ & $42.7 \pm 6.1$ & $9.5 \pm 1.2$ & $57.2 \pm 6.4$ & $48.4 \pm 6.8$ & $67.2 \pm 6.3$ & 100.0 & - \\
\hline $\mathrm{TN}$ & $28.1 \pm 5.3$ & $7.4 \pm 2.9$ & $21.2 \pm 4.1$ & $32.7 \pm 5.3$ & $15.5 \pm 3.2$ & $47.4 \pm 5.6$ & $46.8 \pm 8.3$ & $66.9 \pm 8.2$ & 100.0 & - \\
\hline TDN & $5.7 \pm 1.3$ & $7.6 \pm 1.8$ & $32.1 \pm 4.5$ & $12.0 \pm 3.1$ & $17.7 \pm 2.3$ & $46.0 \pm 7.2$ & $42.8 \pm 9.6$ & $64.3 \pm 9.8$ & 100.0 & - \\
\hline $\mathrm{NO}_{3}{ }^{-}$ & $4.3 \pm 1.2$ & $9.3 \pm 3.4$ & $23.0 \pm 3.2$ & $6.4 \pm 2.8$ & $15.8 \pm 2.4$ & $30.9 \pm 6.8$ & $37.4 \pm 7.8$ & $61.4 \pm 10.2$ & 100.0 & - \\
\hline $\mathrm{NH}_{4}^{+}$ & $7.9 \pm 2.4$ & $8.4 \pm 2.6$ & $28.1 \pm 3.8$ & $9.9 \pm 2.4$ & $17.6 \pm 3.1$ & $54.5 \pm 8.1$ & $47.1 \pm 6.5$ & $74.2 \pm 11.4$ & 100.0 & - \\
\hline
\end{tabular}

a SDs, RGD, VFS, DPs, and RBZ are abbreviations of stone dams, roadside grassed ditch, vegetated filter strip, dry ponds, and riparian buffer zone, respectively.

b Indicates no surface runoff entered the riparian buffer zone.

(ii) Water content of soil usually is very low before a rainfall event in North China for the dry climate. During the rain, dry soil can absorb a large quantity of rainwater and decreases the runoff volume further. (iii) There had many other stone dams in the upstream of the ephemeral stream and several dry ponds in the watershed besides the stone dams and ponds we have studied. These stone dams and ponds could intercept a large quantity of eroding soil and surface runoff before their flows enter the monitoring sites.

\subsubsection{Retention efficiency of single structure}

Owing to the differences in physical characteristics of these structures, spatial location in the watershed, main retention mechanisms for nutrients and the degree of disturbance by human activity, the retention behavior of each structure was different too. During the continuous runoff event on 22 June 2003, due to the huge storage capacity and long detention time, dry ponds had the highest retention rate of water, TSS and $\mathrm{TN}$. Their retention rates were $31.8,42.7$ and $32.7 \%$, respectively. The vegetated filter strip had the highest retention rates for dissolved forms of $\mathrm{TDN}, \mathrm{NO}_{3}{ }^{-}$, $\mathrm{NH}_{4}{ }^{+}$of 32.1, 23.0 and $28.1 \%$, respectively (Table 4). This was the main factor in the higher infiltration rate of water and strongly biological uptake of $\mathrm{N}$ in this area. The riparian buffer zone had a higher retention rate of $\mathrm{NO}_{3}{ }^{-}$possibly due to its high potential for denitrification (Warwick and Hill, 1988; Sabater et al., 2003). The stone dams had a high retention rate of sediment and TN as they reduced the runoff velocity and led to the formation of better detention conditions for particulate matter. The retention rate of $\mathrm{N}$ pollutants by the roadside grassed ditch was low, possibly because of intensive disturbances by human activities. This result suggested that without proper management and maintenance, the performance of these structures would fall below expectations.

During the discontinuous runoff event on 4 August 2002, there was less outflow from these structures, and thus the retention rates of water and pollutants were greatly improved (Table 4). For the dry ponds, the retention rates of water and pollutants could reach $100 \%$ because of zero outflow. Retention rates for the vegetated filter strip were about $60-70 \%$ and higher than those for the stone dams and the roadside grassed ditch, which were about 30-50\%.

During 21 rainfall-runoff events in 2002 and 2003, total retention of water and pollutants by single structure was different (Table 5). During five continuous runoff events, water was mainly retained by dry ponds (Table 5). Due to decrease of capacity by filling up, partly full between rainfalls and penetrating of water, stone dams only retained $468.7 \mathrm{~m}^{3}$ of water. Owing to the better infiltration capacity, the roadside grassed ditch and vegetated filter strip retained 474.7 and $598.5 \mathrm{~m}^{3}$ of water, respectively. The riparian buffer zone only retained $206 \mathrm{~m}^{3}$ of water because of high soil water content in this area. Retention of TSS and $\mathrm{TN}$ by stone dams was the highest. The vegetated filter strip retained most of TDN, $\mathrm{NO}_{3}{ }^{-}$and $\mathrm{NH}_{4}{ }^{+}$. During 16 discontinuous runoff events, retention of water by stone dams was improved largely (Table 5). This was possibly because the relative small volume of surface runoff during each discontinuous runoff event and most of water from hilly land and village could be retained by the dams and gradually infiltrated into soil. Due to the upstream runoff retained largely by the 
Table 5

Retention (mean \pm standard deviation) of water and pollutants by single structure during 5 continuous (a) and 16 discontinuous (b) rainfallrunoff events in 2002 and 2003

\begin{tabular}{|c|c|c|c|c|c|}
\hline & $\mathrm{SDs}^{\mathrm{a}}$ & RGD & VFS & DPs & RBZ \\
\hline \multicolumn{6}{|l|}{ (a) } \\
\hline \multicolumn{6}{|l|}{ Total input } \\
\hline Water $\left(\mathrm{m}^{3}\right)$ & $5198.0 \pm 632.5$ & $4609.8 \pm 552.6$ & $4700.3 \pm 425.3$ & $4460.2 \pm 396.2$ & $3354.1 \pm 234.6$ \\
\hline TSS (kg) & $18887.1 \pm 1458.6$ & $11369.2 \pm 1562.8$ & $11771.1 \pm 1024.9$ & $10043.3 \pm 965.2$ & $6319.7 \pm 711.2$ \\
\hline $\mathrm{TN}(\mathrm{kg})$ & $40.501 \pm 5.695$ & $29.719 \pm 3.268$ & $31.767 \pm 4.567$ & $27.753 \pm 3.011$ & $19.633 \pm 1.668$ \\
\hline TDN (kg) & $24.702 \pm 3.214$ & $24.145 \pm 2.237$ & $24.702 \pm 3.114$ & $17.464 \pm 1.235$ & $17.835 \pm 2.013$ \\
\hline $\mathrm{NO}_{3}^{-}(\mathrm{kg})$ & $12.139 \pm 2.356$ & $12.099 \pm 1.965$ & $12.203 \pm 1.023$ & $10.202 \pm 0.867$ & $9.825 \pm 1.547$ \\
\hline $\mathrm{NH}_{4}^{+}(\mathrm{kg})$ & $8.845 \pm 1.693$ & $8.242 \pm 1.247$ & $8.184 \pm 0.947$ & $5.939 \pm 0.622$ & $6.305 \pm 0.775$ \\
\hline \multicolumn{6}{|l|}{ Total output } \\
\hline Water $\left(\mathrm{m}^{3}\right)$ & $4729.3 \pm 620.1$ & $4135.2 \pm 762.4$ & $4101.8 \pm 632.8$ & $2963.9 \pm 622.5$ & $3148.2 \pm 267.3$ \\
\hline TSS (kg) & $11023.9 \pm 1236.2$ & $10359.1 \pm 965.3$ & $9404.9 \pm 1024.3$ & $5609.5 \pm 498.6$ & $5575.6 \pm 796.3$ \\
\hline $\mathrm{TN}(\mathrm{kg})$ & $28.367 \pm 4.023$ & $26.818 \pm 3.145$ & $24.410 \pm 4.021$ & $18.197 \pm 2.657$ & $16.162 \pm 1.267$ \\
\hline TDN (kg) & $22.711 \pm 2.698$ & $21.753 \pm 3.968$ & $17.965 \pm 1.998$ & $14.986 \pm 3.117$ & $14.589 \pm 2.657$ \\
\hline $\mathrm{NO}_{3}^{-}(\mathrm{kg})$ & $11.458 \pm 1.657$ & $10.701 \pm 2.441$ & $9.164 \pm 1.235$ & $9.310 \pm 1.695$ & $8.067 \pm 1.666$ \\
\hline $\mathrm{NH}_{4}^{+}(\mathrm{kg})$ & $7.942 \pm 0.859$ & $7.355 \pm 1.031$ & $5.732 \pm 0.968$ & $5.218 \pm 1.048$ & $5.065 \pm 0.784$ \\
\hline \multicolumn{6}{|l|}{ Total retention } \\
\hline Water $\left(\mathrm{m}^{3}\right)$ & $468.7 \pm 62.5$ & $474.7 \pm 51.3$ & $598.5 \pm 96.3$ & $1496.3 \pm 285.6$ & $206.0 \pm 39.5$ \\
\hline TSS $(\mathrm{kg})$ & $7863.2 \pm 801.6$ & $1010.0 \pm 124.6$ & $2366.2 \pm 415.3$ & $4433.8 \pm 602.4$ & $744.1 \pm 92.6$ \\
\hline $\mathrm{TN}(\mathrm{kg})$ & $12.135 \pm 1.692$ & $2.901 \pm 0.425$ & $7.357 \pm 1.103$ & $9.556 \pm 1.847$ & $3.471 \pm 0.512$ \\
\hline TDN (kg) & $1.991 \pm 0.215$ & $2.393 \pm 0.224$ & $6.737 \pm 1.124$ & $2.478 \pm 0.329$ & $3.246 \pm 0.584$ \\
\hline $\mathrm{NO}_{3}^{-}(\mathrm{kg})$ & $0.681 \pm 0.097$ & $1.398 \pm 0.301$ & $3.040 \pm 0.327$ & $0.892 \pm 0.128$ & $1.758 \pm 0.204$ \\
\hline $\mathrm{NH}_{4}^{+}(\mathrm{kg})$ & $0.903 \pm 0.106$ & $0.887 \pm 0.117$ & $2.452 \pm 0.421$ & $0.721 \pm 0.163$ & $1.240 \pm 0.166$ \\
\hline \multicolumn{6}{|l|}{ (b) } \\
\hline \multicolumn{6}{|l|}{ Total input } \\
\hline Water $\left(\mathrm{m}^{3}\right)$ & $4560.2 \pm 721.3$ & $3247.9 \pm 536.2$ & $2963.2 \pm 411.6$ & $999.5 \pm 80.1$ & $173.5 \pm 31.2^{\mathrm{b}}$ \\
\hline TSS (kg) & $8649.7 \pm 1024.6$ & $4095.7 \pm 772.3$ & $3235.4 \pm 239.4$ & $927.8 \pm 102.3$ & $14.0 \pm 2.3$ \\
\hline $\mathrm{TN}(\mathrm{kg})$ & $38.775 \pm 3.784$ & $19.970 \pm 4.354$ & $22.068 \pm 4.356$ & $7.242 \pm 0.963$ & $0.873 \pm 0.118$ \\
\hline TDN (kg) & $21.445 \pm 2.696$ & $12.499 \pm 2.014$ & $12.146 \pm 2.234$ & $4.686 \pm 0.773$ & $0.457 \pm 0.063$ \\
\hline $\mathrm{NO}_{3}{ }^{-}(\mathrm{kg})$ & $12.208 \pm 2.354$ & $8.686 \pm 1.367$ & $7.969 \pm 1.247$ & $3.200 \pm 0.524$ & $0.166 \pm 0.021$ \\
\hline $\mathrm{NH}_{4}^{+}(\mathrm{kg})$ & $6.525 \pm 1.036$ & $3.065 \pm 0.635$ & $3.418 \pm 0.448$ & $0.810 \pm 0.129$ & $0.156 \pm 0.016$ \\
\hline \multicolumn{6}{|l|}{ Total output } \\
\hline Water $\left(\mathrm{m}^{3}\right)$ & $2913.6 \pm 402.6$ & $1911.5 \pm 235.8$ & $904.6 \pm 145.3$ & $119.5 \pm 22.1$ & 0 \\
\hline TSS (kg) & $3607.3 \pm 562.4$ & $2162.5 \pm 339.6$ & $1036.3 \pm 213.4$ & $11.1 \pm 1.3$ & 0 \\
\hline $\mathrm{TN}(\mathrm{kg})$ & $20.131 \pm 2.658$ & $11.363 \pm 1.646$ & $7.132 \pm 1.023$ & $0.496 \pm 0.085$ & 0 \\
\hline TDN (kg) & $12.358 \pm 1.824$ & $6.969 \pm 0.965$ & $5.224 \pm 0.658$ & $0.253 \pm 0.064$ & 0 \\
\hline $\mathrm{NO}_{3}^{-}(\mathrm{kg})$ & $9.226 \pm 1.269$ & $5.298 \pm 0.942$ & $4.236 \pm 0.669$ & $0.081 \pm 0.014$ & 0 \\
\hline $\mathrm{NH}_{4}^{+}(\mathrm{kg})$ & $2.897 \pm 0.448$ & $1.580 \pm 0.234$ & $0.861 \pm 0.124$ & $0.083 \pm 0.016$ & 0 \\
\hline \multicolumn{6}{|l|}{ Total retention } \\
\hline Water $\left(\mathrm{m}^{3}\right)$ & $1646.6 \pm 329.4$ & $1336.4 \pm 156.3$ & $2058.6 \pm 311.4$ & $880.0 \pm 112.6$ & $173.5 \pm 31.2$ \\
\hline TSS (kg) & $5042.4 \pm 499.6$ & $1933.2 \pm 236.8$ & $2199.1 \pm 299.6$ & $916.7 \pm 145.4$ & $14.0 \pm 2.3$ \\
\hline $\mathrm{TN}(\mathrm{kg})$ & $18.644 \pm 2.487$ & $8.607 \pm 1.248$ & $14.937 \pm 1.895$ & $6.745 \pm 1.024$ & $0.873 \pm 0.118$ \\
\hline TDN (kg) & $9.087 \pm 1.548$ & $5.530 \pm 0.869$ & $6.922 \pm 1.024$ & $4.433 \pm 0.532$ & $0.457 \pm 0.063$ \\
\hline $\mathrm{NO}_{3}{ }^{-}(\mathrm{kg})$ & $2.982 \pm 0.364$ & $3.388 \pm 0.624$ & $3.733 \pm 0.369$ & $3.119 \pm 0.449$ & $0.166 \pm 0.021$ \\
\hline $\mathrm{NH}_{4}^{+}(\mathrm{kg})$ & $3.628 \pm 0.545$ & $1.485 \pm 0.326$ & $2.557 \pm 0.412$ & $0.727 \pm 0.115$ & $0.156 \pm 0.016$ \\
\hline
\end{tabular}

${ }^{\text {a }}$ SDs, RGD, VFS, DPs, and RBZ are abbreviations of stone dams, roadside grassed ditch, vegetated filter strip, dry ponds, and riparian buffer zone, respectively.

b Only 5 out of the 16 discontinuous rainfall events generated any input to the riparian buffer zone. 
Table 6

Coefficient of variation $(\%)$ of retention rate of single structure during different rainfall-runoff events

\begin{tabular}{|c|c|c|c|c|c|c|}
\hline & $\mathrm{SDs}^{\mathrm{a}}$ & RGD & VFS & DPs & RBZ & Mean \\
\hline \multicolumn{7}{|c|}{ Continuous runoff events $(n=5)$} \\
\hline TSS & 23.1 & 32.8 & 18.7 & 16.3 & 19.8 & $22.1 \mathrm{a}$ \\
\hline $\mathrm{TN}$ & 24.5 & 36.7 & 21.9 & 14.8 & 20.1 & $23.6 \mathrm{a}$ \\
\hline TDN & 30.6 & 35.1 & 22.9 & 23.8 & 21.4 & $26.8 \mathrm{a}$ \\
\hline $\mathrm{NO}_{3}^{-}$ & 33.8 & 41.3 & 20.7 & 21.9 & 20.3 & $27.6 \mathrm{a}$ \\
\hline $\mathrm{NH}_{4}^{+}$ & 29.6 & 33.7 & 20.6 & 21.3 & 23.7 & $25.8 \mathrm{a}$ \\
\hline Mean & $28.3 \mathrm{~b}$ & $35.9 \mathrm{a}$ & $21.0 \mathrm{c}$ & $19.6 \mathrm{c}$ & $21.1 \mathrm{c}$ & \\
\hline \multicolumn{7}{|c|}{ Discontinuous runoff events $(n=16)$} \\
\hline TSS & 20.4 & 24.6 & 17.9 & 6.5 & $-{ }^{\mathrm{b}}$ & $17.4 \mathrm{a}$ \\
\hline $\mathrm{TN}$ & 23.8 & 21.7 & 16.3 & 9.2 & - & $17.8 \mathrm{a}$ \\
\hline TDN & 18.5 & 23.7 & 20.4 & 11.4 & - & $18.5 \mathrm{a}$ \\
\hline $\mathrm{NO}_{3}{ }^{-}$ & 21.7 & 24.7 & 16.4 & 10.7 & - & $18.4 \mathrm{a}$ \\
\hline $\mathrm{NH}_{4}^{+}$ & 20.9 & 23.9 & 15.7 & 11.3 & - & $18.0 \mathrm{a}$ \\
\hline Mean & $21.1 \mathrm{~b}$ & $23.7 \mathrm{a}$ & $17.3 \mathrm{c}$ & $9.8 \mathrm{~d}$ & - & \\
\hline
\end{tabular}

Different letters after means indicate significantly difference according to Duncan multiple range test at $P<0.001$.

a SDs, RGD, VFS, DPs, and RBZ are abbreviations of the stone dams, roadside grassed ditch, vegetated filter strip, dry ponds, and riparian buffer zone, respectively.

${ }^{\mathrm{b}}$ Indicates no surface runoff entered the riparian buffer zone.

roadside grassed ditch and vegetated filter strip, the input of water to dry ponds was small (only about $880 \mathrm{~m}^{3}$ ). Retention of TSS and TN by stone dams still was the highest. Due to improvement of retention of polluted runoff (especially for the runoff from village), stone dams also had the highest retention of TDN and $\mathrm{NH}_{4}{ }^{+}$. Retention of $\mathrm{NO}_{3}{ }^{-}$by the vegetated filter strip was the highest for its strong biological absorption of nutrients and better infiltration capacity. Only 5 out of the 16 discontinuous rainfall events generated any input to the riparian buffer zone and there had no surface runoff exported from the outlet of the watershed.

Note that the retention efficiency of pollutants of several structures during continuous runoff events at this site was relatively low compared with that obtained by other researchers for the same type of structure (Cooper and Knight, 1990; Daniels and Gilliam, 1996; Núñez et al., 1995). This difference was possibly because: (i) In a continuous runoff event, it was likely to form concentrated flow than sheet flow, which limited the retention performance of several structures. (ii) The scales of these structures were relatively insufficient in treating the large runoff volume generated in the continuous runoff event. (iii) These landscape structures were not designed specially for the job of treating diffuse polluted runoff. They have many original purposes for using. Under less management conditions, disturbances as a result of human activities affected the retention efficiency. Despite the reasons outlined earlier, these buffer structures as part of the whole system, played an important role in controlling the transportation of $\mathrm{N}$ pollutants and sediment downstream (Table 3).

\subsubsection{Stability of retention performance by single structure}

Retention processes taking place on the flow pathway were closely influenced by the hydrological conditions. A statistical analysis of rainfall-runoff events of all five continuous and sixteen discontinuous runoff events, revealed that the stability of the structures (based on the coefficient of variation (CV) values of the retention performance dataset) differed significantly (Table 6). The CV of retention rates in discontinuous events was lower than that of continuous events. This suggests that the retention performance of these structures was more stable in the discontinuous runoff condition. This was possibly because the existing condition of these structures is suitable for the treatment of the relatively small volume of runoff. Under the continuous runoff conditions, the vegetated filter strip, dry ponds and the riparian buffer zone were more steady than the roadside grassed ditch and stone dams. Under the discontinuous runoff conditions, there was a signifi- 
cant difference $(p<0.001)$ in stability between these structures. Dry ponds had the lowest mean CV of pollutants retention rates during both types of runoff events (19.6 and 9.8\%) because of the steady detention condition. Due to the disadvantageous influences as a result of human disturbance, the roadside grassed ditch had the highest mean $\mathrm{CV}$ of retention rates (35.9 and $23.7 \%$ ). There was no significant difference in mean $\mathrm{CV}$ for different pollutants in different runoff conditions, suggesting that this system did not significantly change the retention efficiency of sediment and various forms of $\mathrm{N}$.

\subsection{Primary control mechanisms for sediment and $N$ retention}

All processes which occur in the watershed are closely connected with hydrological conditions. Obversely, landscapes in the watershed can determine the hydrological dynamics of water flow transporting in the flow pathways. The change of flow velocity and runoff volume plays important roles in the transporting process, detention time and export load of pollutants. As a system composed of many types of buffer/detention landscape structures, the latter can cause decline in conduit capacity and an increase in the retention of water and $\mathrm{N}$ pollutants through their hydrological control on flow velocity and runoff volume.

The flow velocity fluctuates before it reaches the reservoir (Fig. 4). It generally gradually decreases from the inlet to the outlet in each structure and then gradually increases in the stream channel between two structures in the absence of control structures. The flow velocity increases sharply at the junction point when there is a large tributary. During the continuous runoff event on 22 June 2003, the flow velocity was 37.2 and $11.1 \mathrm{~cm} \mathrm{~s}^{-1}$ at the inlet and outlet of the system, respectively. Due to the large tributary flow from the village area, as a result of the low infiltration rate of the ground, there was a sharp increase in the flow velocity from 10.4 to $25.8 \mathrm{~cm} \mathrm{~s}^{-1}$. However, the velocity decreases thereafter to $12.7 \mathrm{~cm} \mathrm{~s}^{-1}$ when the flow encounters a stone dam. Because of transporting in the sloping stream channel, the flow velocity gradually increased and reached $33.1 \mathrm{~cm} \mathrm{~s}^{-1}$ at the inlet of the roadside grassed ditch. Due to an enhancement of roughness brought about by vegeta-
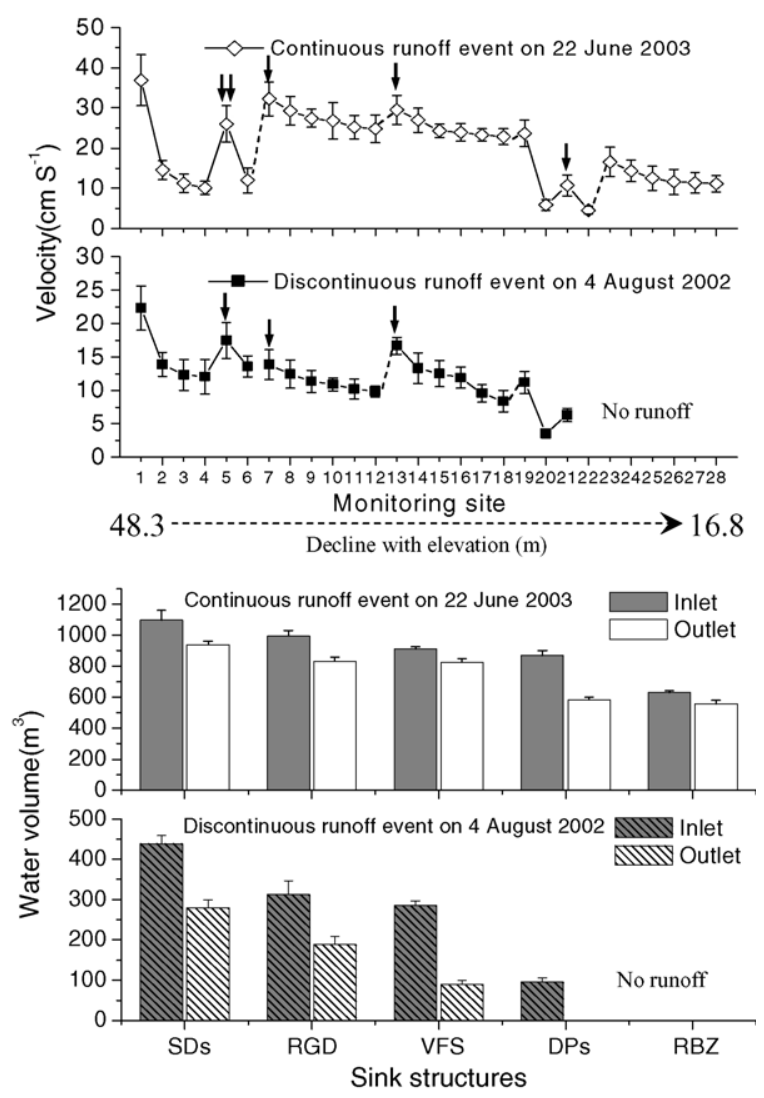

Fig. 4. The spatial variation of surface flow velocity and runoff volume in the flow pathway during the continuous runoff event on 22 June 2003 and the discontinuous runoff event on 4 August 2002. The dashed line stands for runoff transporting in the stream channel between two structures. During the discontinuous runoff event on 4 August 2002, no water entered the last seven monitoring sites because no water was exported from the dry ponds. SDs, RGD, VFS, DPs, and RBZ are abbreviations of the stone dams, roadside grassed ditch, vegetated filter strip, dry ponds, and riparian buffer zone, respectively. Black arrows represent temporary tributary flow from various land uses during rainfall events.

tion, the flow velocity decreased to some extent. The velocity increased again at the junction point of the inlet of fieldborder vegetated filter strip for the entering of tributary flow. Flow velocity decreased from $29.5 \mathrm{~cm} \mathrm{~s}^{-1}$ of inlet to $22.3 \mathrm{~cm} \mathrm{~s}^{-1}$ of outlet because of the abundant vegetation in the strip. In the ponds zone, the flow velocity of outlet is very low $\left(4.4 \mathrm{~cm} \mathrm{~s}^{-1}\right)$ due to a sharp decrease in kinetic energy. The buffer zone also demonstrates a higher propensity for the flow velocity to decrease from $16.5 \mathrm{~cm} \mathrm{~s}^{-1}$ of 
inlet to $11.1 \mathrm{~cm} \mathrm{~s}^{-1}$ of outlet. During the discontinuous runoff event on 4 August 2002, the change in flow velocity is relatively small for the intermittent transportation of water and the relatively small runoff volume. During this event, no runoff entered the last seven monitoring sites (the buffer zone) because no water was exported from the outlet of the dry ponds.

Runoff volume was reduced from the inlet to outlet of the system for infiltration or storing by each structure (Fig. 4). The decrease in runoff volume further reduces the flow kinetic energy. This is beneficial for the settling of sediment and particulate $\mathrm{N}$ pollutants and reduces channel erosion. During the continuous runoff event on 22 June 2003, the polluted runoff volume was cut down from $1119.2 \mathrm{~m}^{3}$ of total input to $556.9 \mathrm{~m}^{3}$ of total output. Especially in the ponds zone, the volume of reduction was larger. During this event, there was overflow due to the small size of the ponds. The export volume of polluted runoff would be reduced further with larger ponds. In the discontinuous runoff event, the decreased runoff volume was more notable as a result of the relatively small runoff volume.

Hydrological control by these structures is the primary control mechanisms of this system which decreases the kinetic energy of the runoff, reduces channel erosion and, because of the prolonged detention time, provides favorable conditions for the retention and transformation of sediment and $\mathrm{N}$. And the longer detention time created favorable conditions for biological, chemical and physical reactions that can lead to the removal of pollutants.

The results of this research show that a landscape buffer structures system is effective in the reduction of the export load of sediment and $\mathrm{N}$ by surface flow on watershed scale. It follows that similar efficient technical or management measures can be taken to reduce the export of nutrient-rich flow from the contributing basins and to protect regional water resources in other areas, especially those areas with relatively dry climates. Different forms and types of landscape buffer structures can be used. Certainly, N pollutants (especially for nitrate) also can be transported by underground flow under appropriate conditions. For Yuqiao Reservoir, underground flow actually occurs during rainy season and contributes about $10 \%$ of the input water and $9 \%$ load of $\mathrm{TN}$, respectively (Zhu, 1991). Downward percolation from water held by buffer structures probably contributes a part to this flow, taking with it a proportion of dissolved N. This problem needs to be considered when similar types of structures were used to control flow of nutrients leaching from agricultural landscape. For the buffer structures being covered by flourish vegetation, the fate of nutrients in the form of biomass is also important for the control effect of nutrients flow. Vegetation should be harvested in appropriate time and take part in the recycling process of nutrients in the watershed ecosystem so as to avoid being flushed downstream when stream flow is strong enough. For the longer-term improvement in downstream water quality, good management and maintenance of these structures is necessary.

\section{Conclusions}

Diversified artificial or natural landscape buffer structures, which include stone dams, a roadside grassed ditch, a vegetated filter strip, dry ponds and a riparian buffer zone, compose a sink structures system for the control of the transport process of sediment and $\mathrm{N}$ pollutants. Significant amounts of sediment and N can be retained from surface runoff as a result of the purification by this system.

During continuous runoff events, the retention rate of water by the system was determined to be $50.2 \%$, TSS to be $72.7 \%$, TN $66.1 \%$, TDN $52.5 \%, \mathrm{NO}_{3}{ }^{-}$ $43.6 \%$ and $\mathrm{NH}_{4}{ }^{+} 51.6 \%$, respectively. During discontinuous events, these retention rates were higher. Dry ponds and stone dams are more effective for the retention of particulate $\mathrm{N}$, while the vegetated filter strip and riparian buffer zone are more effective for dissolved $\mathrm{N}$ forms. The system constituted by buffer structures has a good capacity for the reduction of sediment and the flow of both forms of N. The dry pond was the reliable structure for controlling pollutants export in this watershed, while the roadside grassed ditch was highly unstable.

Hydrological control by this system of flow velocity and runoff volume was the main mechanism in the reduction of sediment and $\mathrm{N}$. These landscape buffer structures decrease the kinetic energy of runoff and, as the result of the prolonged detention time, provide good conditions for the retention and transformation of sediment and $\mathrm{N}$. 


\section{Acknowledgements}

This study was conducted under the auspices of the National Key Project for Basic Research (2002CB412308), the National Natural Sciences Foundation of China (40171003) and Key Project of Knowledge Innovation Program of CAS (KZCX1SW-12). The authors also acknowledge Paul Brewster for English correction of the manuscript.

\section{References}

APHA, 1985. Standard Methods for the Examination of Water and Wastewater, 16th ed. Washington DC, USA, pp. 373412.

Ator, S.M., Ferrari, M.J., 1997. Nitrate and selected pesticides in ground water of the Mid-Atlantic Region. USGS Water Resources Investigation Report 97-4139, Baltimore, MD, USA.

Carpenter, S.R., Caraco, N.F., Correll, D.L., Howarth, R.W., Sharpley, A.N., Smith, V.H., 1998. Nonpoint pollution of surface waters with phosphorus and nitrogen. Ecol. Appl. 8, 559568.

Cooper, C.M., Knight, S.S., 1990. Nutrient trapping efficiency of a small sediment detention reservoir. Agric. Water Manage. 18, $149-158$.

Cooper, J.R., Gilliam, J.W., Daniels, R.B., 1987. Riparian areas as filters for agricultural sediment. Soil Sci. Soc. Am. J. 51, 416420.

Creed, I.F., Band, L.E., 1998. Export of nitrogen from catchments within a temperate forest: Evidence for a unifying mechanism regulated by variable source area dynamics. Water Resour. Res. $34,3105-3120$.

Daniels, R.B., Gilliam, J.W., 1996. Sediment and chemical load reduction by grass and riparian filters. J. Environ. Qual. 60, 226251.

Dickey, E.C., Vanderholm, D.H., 1981. Vegetative filter treatment of livestock feedlot runoff. J. Environ. Qual. 10, 279-284.

Diederik, T.V., Auke, B., Paul, C.M., 1998. Agricultural nutrient losses to surface water in the Netherlands: impact, strategies, and perspectives. J. Environ. Qual. 27, 4-11.

Dillaha, T.A., Sherrard, J.H., Lee, D., Mostaghimi, S., Shanholtz, V.O., 1988. Evaluation of vegetative filter strips as a best management practice for feed lots. J. Water Pollut. Control Fed. 60, 1231-1238.

Dillaha, T.A., Renear, R.B., Mostaghimi, S., Lee, D., 1989. Vegetative filter strips for agricultural nonpoint source pollution control. Trans. Am. Soc. Agric. Eng. 32, 513-519.

Downing, J.A., McClain, M., Twilley, R., Melack, J.M., Elser, J., Rabalais, N.N., Lewis Jr., W.M., Turner, R.E., Corredor, J., Soto, D., Yanez-Arancibia, A., Kopaska, J.A., Howarth, R.W., 1999. The impact of accelerating land-use change on the N-cycle of tropical aquatic ecosystems: current conditions and projected changes. Biogeochemistry 46, 109-148.
FAO, 1990. FAO-UNESCO soil map of the world, revised legend. Soils Bulletin No. 60. FAO, Rome.

Fleischer, S., Gustafson, A., Joelsson, A., Pansar, J., Stibe, L., 1994. Nitrogen removal in created ponds. Ambio 26, 349-357.

Forman, R.T.T., Gordon, M., 1986. Landscape Ecology. Willey, New York, 619 pp.

Hessen, D.O., Hindar, A., Holtan, G., 1997. The significance of nitrogen runoff for eutrophication of freshwater and marine recipients. Ambio 26, 312-320.

Hill, A.R., 1996. Nitrate removal in stream riparian zones. J. Environ. Qual. 25, 743-755.

Hillbricht-Ilkowska, A., Rybak, J., Rzepecki, M., 2000. Ecohydrological research of lake-watershed relations in diversified landscape (Masurian Lakland, Poland). Ecol. Eng. 16, 91-98.

Howarth, R.W., 1988. Nutrient limitation of net primary production in marine ecosystems. Annu. Rev. Ecol. Syst. 19, 89-110.

Hunsaker, C.T., Levine, D.A., 1995. Hierarchical approaches to the study of water quality in rivers. Bioscience 45, 193-203.

Jordan, T.E., Correll, D.L., Weller, D.E., 1993. Nutrient interception by a riparian forest receiving inputs from adjacent cropland. J. Environ. Qual. 22, 467-473.

Kronvang, B., Aertebjerg, G., Grant, R., Kristensen, P., Hovmand, M., Kirkegaard, J., 1993. Nationwide monitoring of nutrients and their ecological effects: State of the Danish aquatic environment in Denmark: impact of agriculture. Mar. Freshwater Res. 46, 167-177.

Kuusemets, V., Mander, Ü., 2002. Nutrient flows and management of a small watershed. Landsc. Ecol. 17, 59-68.

Leonardson, L., Bengtsson, L., Davidsson, T., Persson, T., Emanuelsson, U., 1994. Nitrogen retention in artificially flooded meadows. Ambio 23, 332-341.

Leu, H.G., Ouyang, C.F., Su, J.L., 1996. Effects of flow velocity changes on nitrogen transport and conversion in an open channel flow. Water Res. 30, 2065-2071.

Ma, L.S., 1997. Nitrogen management and environmental and crop quality. In: Zhu, Z.L., Wen, Q.X., Freney, J.R. (Eds.), Nitrogen in Soils of China: Developments in Plant and Soil Sciences, vol. 74. Kluwer Academic Publishers, Dordrecht, The Netherlands, pp. 303-321.

Núñez, A., López, E., Díaz-Fierrods, F., 1995. Vegetated filter strips for wastewater purification: a review. Bioresour. Technol. 51, 13-22.

Peterjohn, W.T., Correll, D.L., 1984. Nutrient dynamics in an agricultural watershed: observations on the role of a riparian forest. Ecology 65, 1466-1475.

Pomogyi, P., 1993. Nutrient retention by the Kis-Balaton Water Protect System. Hydrobiologia 251, 309-320.

Puckett, L.J., 1995. Identifying the major sources of nutrient water pollution. Environ. Sci. Technol. 29, 408-414.

Ryszkowski, L., 1989. Control of energy and matter fluxes in agricultural landscapes. Agric. Ecosyst. Environ. 27, 107118.

Sabater, S., Butturini, A., Clement, J.-C., Burt, T., Dowrick, D., Hefting, M., Maître, V., Pinay, G., Postolache, C., Rzepecki, M., Sabater, F., 2003. Nitrogen removal by riparian buffers along a European climatic gradient: patterns and factors of variation. Ecosystems 6, 20-30. 
SAS Institute, 1996. SAS System for Windows v6.12. SAS Institute Inc., Cary, NC, USA.

Shan, B.Q., Yin, C.Q., Li, G.B., 2002. Transport and retention of phosphorus pollutants in the landscape with a traditional, multipond system. Water Air Soil Pollut. 139, 15-34.

Smil, V., 1991. Population growth and nitrogen: an exploration of a critical existential link. Popul. Dev. Rev. 17, 569-601.

Tabacchi, E., Lambs, L., Guilloy, H., Planty-Tabacchi, A.-M., Muller, E., Décamps, H., 2000. Impacts of riparian vegetation on hydrological processes. Hydrol. Process 14, 29592976.

Tim, U.S., Jolly, R., Liao, H.H., 1995. Impact of landscape feature and feature placement on agricultural nonpoint source pollution control. J. Water Resour. Plan. Manage. 121, 463-470.

Turner, M.G., 1987. Landscape Heterogeneity and Disturbance. Springer Verlag, New York, 239 pp.

Uusi-Kämppä, J., Braskerud, B., Jansson, H., Syversen, N., Uusitalo, R., 2000. Buffer zone and constructed wetlands as filters for agricultural phosphorus. J. Environ. Qual. 29, 151-158.
Vitousek, P.M., Howarth, R., 1991. Nitrogen limitation on land and in the sea: how can it occur? Biogeochemistry 13, 87-115.

Vought, L.B.-M., Dahl, J., Pedersen, C.L., Lacoursière, J.O., 1994. Nutrient retention in riparian ecotones. Ambio 23, 342-348.

Vought, L.B.-M., Pinay, G., Fuglsang, A., Ruffinoni, C., 1995. Structure and function of buffer strips from a water quality perspective in agricultural landscapes. Landsc. Urban Plan. 31, 323-331.

Warwick, J., Hill, A.R., 1988. Nitrate depletion in the riparian zone of a small woodland stream. Hydrobiologia 157, 231-240.

Yan, W.J., Yin, C.Q., Tang, H.X., 1998. Nutrient retention by multipond systems: mechanisms for the control of nonpoint source pollution. J. Environ. Qual. 27, 1009-1017.

Yin, C.Q., Zhao, M., Jin, W.G., Lan, Z.W., 1993. A multi-pond system as a protective zone for the management of lakes in China. Hydrobiologia 251, 321-329.

Zhu, X., 1991. Control of Eutrophication of Yuqiao Reservoir. Science \& Technology Press of Tianjin, Tianjin, China, pp. 12-13 (in Chinese). 